\title{
Aquaculture \& Marine Biotechnology Programme in India
}

\author{
Ninawe $\mathrm{AS}^{1^{*}}$ and Sahul Hameed $\mathrm{AS}^{2}$ \\ ${ }^{1}$ Department of Biotechnology, Ministry of Science \& Technology, India \\ ${ }^{2}$ Department of Biotechnology, C Abdul Hakeem College, India
}

Submission:March 21, 2017; Published: May 02, 2017

*Corresponding author: : Ninawe AS, Department of Biotechnology, Ministry of Science \& Technology, CGO Complex, Lodhi Road, New Delhi-110003,Email: ninawe.dbt@nic.in /cah_sahul@hotmail.com

\section{Mini Review}

Marine biotechnology has been a major focus world-wide through bio-discovery of marine microbes, invertebrates, microalgae and macro-algae. In the commercial production of bioactive molecules and pharmaceuticals it plays a pivotal role. The global market for products from marine biotechnology is expected to reach over US $\$ 4$ billion by 2015 and therefore marine bio-resources emerging with a lot of scope for the health and well being of aquaculture production in the country through marine bio-business.

DBT has been encouraging the scopes of Aquaculture \& Marine Biotechnology, covering both R\&D and approached broad aspects through competitive grant scheme with the operational inputs from the Task Force Committee and with incentive during Brain Storming Sessions and workshops. For economically important finfish and shellfish species, and also seaweeds, the department has been focusing on developing technology for seed production and grow-out pond culture for the past two decades. It has been proved that the technology developed by the department can produce fresh water prawn up to 1.5 to 2.0ton/ha. Farmers who implemented this technology have got benefited. DBT has demonstrated highly remarkable production rate in shrimp culture through semi intensive shrimp culture technology by producing 10t/ha per annum in two crops.

Research on induced breeding and maturation in commercially essential fish and shrimp species has been conducted. Researchers have also been engrossed on various aspects such as Diagnostics, Vaccines, Recombinant products, Anti-microbial Peptides, Immunostimulants, High-energy and high-protein Aquaculture Feed, Fish Spawning Agents, Human Therapeutics (Omega-3 and 6), Water Quality Management, value addition and product \& process development. Inventorisation and digitalization of marine and coastal bioresources pertaining to marine mollusk are being carried out. Public-Private Partnerships were encouraged for leads in water re-circulatory system and management of metabolite load in the culture operations.

During the last plan (2007-12), the Department has given priority to aquatic health management. Molecular markers assisted technology for screening healthy population of shrimp/ fish brooders was the major concern. In India, the loss of shrimp due to WSSV has been estimated to be about US\$150 million per year (CIBA, 2008). Implementation of advanced technologies especially biotechnological tools has made an impact in combating the disease risk. In addition, current technologies are contributing to the future improvement of aquaculture production. For this, the efforts were directed towards the development of a number of conventional and molecular diagnostics and therapeutics. These efforts have also been strengthened through Indo-Norwegian joint collaborative projects on development of vaccines against viral and bacterial pathogens encountered in Indian aquaculture systems. As the outcome of DBT funded projects, several sensitive and specific diagnostic assays have been developed to detect viral pathogens such as white spot syndrome virus (WSSV), fish nodavirus (VNN) and other pathogenic viruses. These successful diagnostics based on either single step or nested PCR methods are available in the names of Ampli-WSSV kit, Dr. Sahul's Kit, Genei WSSV kit, Mangalore Biotech kit, IQ2000 etc., Apart from these methods, loop mediated isothermal amplification method (LAMP) has been developed for diagnosing WSSV and white tail disease (WTD) associated Macro brachium rosenbergii nodavirus (MrNV) and extra small virus (XSV).

Vaccine play significant role to prevent diseases in aquaculture systems. The DBT has financed many R\&D projects to design vaccines against diverse viral and bacterial pathogens of fish and shrimp. Recombinant and DNA vaccines have been developed for Aeromonas hydrophila, Vibrio anguillarum, Edwardsiella tarda, fish nodavirus, WSSV and Mr NV. Genes such as OmpTS, 
Aha1 and OmpW has been used to develop recombinant vaccines and their efficacy against $A$. hydrophila was tested and observed to be effective. Inactivated whole WSSV vaccine, recombinant subunit vaccine and DNA vaccine using different viral genes have been proved to be beneficial in small scale against WSSV in shrimp. Protection of Fenneropenaeus indicus from WSSV has been demonstrated using formalin-inactivated WSSV. Of all viral genes, VP28 structural gene of WSSV is found to be the most suitable candidate gene for demonstrating vaccine based protection. Survival rate in experimental post infection of virus in Penaeus monodon by intramuscular challenge showed maximum efficiency with pVP28 against WSSV. The DBT has also implemented Indo-Norwegian program to develop vaccines for viral and bacterial pathogens encountered in Indian aquaculture systems. At the end of this program, the vaccines would be available for use in the aquaculture sector.

For the protection of cultivable organisms from viral and bacterial pathogens immunostimulants of bacterial or plant origin of different types have been developed. Laboratory studies indicate that administration of a commercial Aquastim MBL by immersion or through feed stimulates the immune system of shrimp in hatchery, showing significant improvement in survival. Immuzone derived from a group of terrestrial plants through extraction process is used commercially as herbal immunostimulant. The defensive mechanism of shrimps and other crustaceans improved by a group of compounds through the synergic effect. It does not contain Glucans and Mannans. Immuzone increases the defensive mechanism of shrimp by enhancing the hemocytic activities. Higher levels of prophenol oxidase and nitric oxide were observed after ingestion of immuzone coated feed in pond reared shrimp.

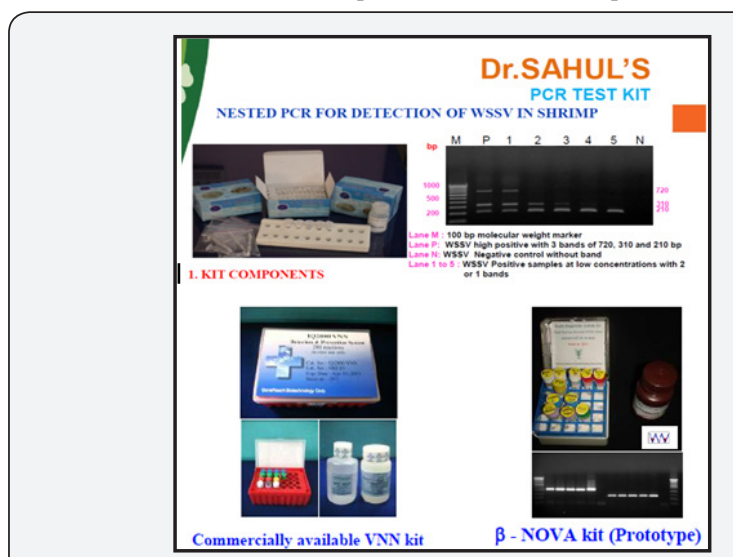

Figure 1: Indigenous diagnostic kits developed for white spot syndrome virus of shrimp and fish Nodavirus.

Recently, the DBT funded a project on application of RNAi to control WSSV in shrimp and good leads have been achieved. To produce WSSV-free shrimp brooders and seeds the project has been further extended by another three year to apply these leads. For pathogen detection, toxicological studies, carcinogenesis, cellular physiology, and genetic regulation and expression studies tissue culture and the development of cell lines from fish are important. To grow fish cell lines from marine and freshwater fish the DBT has funded projects to different research institutes. More than 50 fish cell lines have been obtained from economically important fish for scientific research within a short period of six years. The DBT has also funded NBFGR to establish a National Repository to maintain these cell lines for future use (Figure 1).

The DBT has also funded a project to develop feed for aquaculture sector. An enrichment aquafeed with cellulolytic and amylolytic microbes has been developed for feeding Lates calcarifer (Asian seabass), Chanos chanos (milk fish), Mugil cephalus (Grey mullet) and Etroplus suratensis (Pearl spot). Probiotics are 'bio-friendly agents', such as Lactobacillus, yeasts and Bacillus sp. They could be employed in the culture environment to suppress and fight against pathogenic bacteria and to enhance the growth of the farm cultured organisms. Even against the environmental stressors they even play a significant role in promoting the innate immunity of the organism. Soil probiotic to break down the organic load at the pond bottom, antagonistic probiotic for killing bacterial pathogens, water probiotics for keeping the water clean and gut probiotics which help in digestion are being applied in Indian aquaculture systems. The DBT has funded quite a number of projects to develop probiotics for aquaculture use (Figure 2).
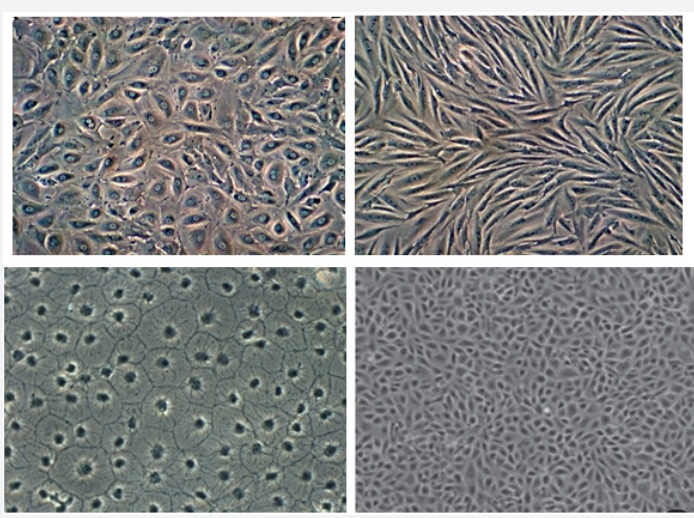

Figure 2: Cell lines developed from Indian fish species.

HRD support to Aquaculture \& Marine Biotechnology was the major initiative during 2000-2005. The programme for fisheries personnel was successfully operated through the institutes at CIFE, CIFT, CIFA and CDFD by imparting about 3-6 months of both theoretical and hands on training. Under this programme, more than 300 scientists and researchers have been trained and many of them have started working on applied aspects and have published many papers in reputed journals, filed patents and have brought out commercial leads. The department has taken a major initiative in strengthening the infrastructure and facility to bring about academic excellence in Aquaculture \& Marine Biotechnology both in basic and applied aspects. During the $10^{\text {th }}$ plan, the Department has provided support to two institutions by sanctioning a dedicated programme support on Aquaculture 
\& Marine Biotechnology at College of Fisheries, Mangalore, and Cochin University of Science \& Technology, Cochin.

The Department has been giving major attention on the creation of a Centre of Excellence in the area of Marine Biotechnology addressing important areas like RNAi technology, nano-technology, extremophiles, cell-line development and their application, user friendly diagnostics and vaccines for new emerging diseases, immuostimulants, brood-stock development, production of disease free seeds, low cost feed development, and post harvest technology, natural product development, biofuels from marine algae, novel microbial enzymes for industrial applications, novel drugs from marine organisms for medicinal value etc.

The Department is also very optimistic about the establishment of an Institute on Marine Biotechnology with its focus on Marine \& Microbial Biotechnology, considering the fact that India has huge marine resources with the longest coast line and is blessed with diverse marine bio-diversity. This will be vigorously pursued during the $12^{\text {th }}$ plan of the Country with the aim of harnessing the potential of the emerging marine biotechnology with a strong foundation in basic research and a translational research.

Industry promotion schemes are being supported by the Department for product process development with the involvement of small and medium enterprises working in biotechnology. The dedicated industry promotion schemes, SBIRI and BIPP have benefitted the sector by providing funding to aquaculture based companies who are seriously engaged in products and process development of high value and export potential. The Department is also supporting international collaborations in the various sectors of biotechnology including marine biotechnology. Indo-Norway collaboration on fish and shellfish vaccine development has shown good leads for vaccine development.

\section{Your next submission with Juniper Publishers will reach you the below assets}

- Quality Editorial service

- Swift Peer Review

- Reprints availability

- E-prints Service

- Manuscript Podcast for convenient understanding

- Global attainment for your research

- Manuscript accessibility in different formats

( Pdf, E-pub, Full Text, Audio)

- Unceasing customer service

Track the below URL for one-step submission https://juniperpublishers.com/online-submission.php 
The DBT is also working on bio-fuels programme and is supporting various R\&D activities under Energy Bioscience programme. The focus has been on bio-energy and bio-fuels including biodiesel/bio-ethanol using different feed stocks. Algal Bio-fuel has an enormous potential. The priority areas identified are: Collection, screening, taxonomic identification, algal biodiversity; development of uni-algal cultures of suitable strains, and establishment of culture collection centres. The DBT has supported Biotech Parks in few states, namely Biotechnology Parks and Incubation Centres in Lucknow, UP, Biotechnology Park at Bangalore (Karnataka), and Biotechnology Parks, in the states of Kerala, Punjab and Himachal Pradesh. These biotech parks have been established to produce biotechnologists and entrepreneurs having strong foundation in research and innovation and to promote product advancement and innovation through the biotechnology industrial cluster. As such there is no dedicated marine biotechnology park supported by DBT. Efforts are on to study the request from the promising states for the establishment of a biotech incubator and biotech parks in the states. The infrastructure and manpower support provided by the Department of Biotechnology, The University of Science and Technology at Cochin, Kerala, is working on projects in Marine Biotechnology covering aspects like genotypic characterization, gene-sequencing and isolation of novel enzymes and marine natural products and biomaterials, as well as establishing a database on marine biotechnology. 
